\title{
МЕТОД ДИФФЕРЕНЦИРУЮЩЕГО РАСТВОРЕНИЯ В ИССЛЕДОВАНИИ ХИМИЧЕСКОГО СОСТАВА МЕДЬ-ЖЕЛЕЗО СМЕШАННОГО ОКСИДА СО СТРУКТУРОЙ КУБИЧЕСКОЙ ШПИНЕЛИ
}

Почтарь А. А., Комова О.В., Нецкина О.В.

ФГБУН ФИЦ Институт катализа им. Г. К. Борескова СО РАН, Новосибирск, Россия po4tar@catalysis.ru

DOI: 10.26902/ASFE-11_68

Феррит меди является широко исследуемым оксидом в силу его высокопроводящих и магнитных свойств, а также разнообразных каталитических применений. В докладе представлены результаты применения стехиографического метода дифференцирующего растворения (ДР) для определения химического состава медь-железосодержащих катализаторов со структурой кубической шпинели. Применение метода ДР было обусловлено его безэталонной природой, возможностью проведения количественного фазового анализа с высокой чувствительностью как кристаллических, так и аморфных образцов.

Методом ДР были исследованы образцы ферритов меди, синтезированные горением глицин-нитратных предшественников, прокаленные при температуре 300,700 и $1100{ }^{\circ} \mathrm{C}$. Метод послойного горения глицин-нитратного предшественника является одним из эффективных способов получения наноразмерных частиц медь-железо смешанного оксида структуры кубической шпинели [1,2]. Присутствие меди в структуре кубической шпинели $\mathrm{CuFe}_{2} \mathrm{O}_{4}$ сложно подтвердить рентгенографическим методам без дополнительных исследований, поскольку структуры $\mathrm{Fe}_{3} \mathrm{O}_{4}$ и $\mathrm{Cu}_{1-\mathrm{x}} \mathrm{Fe}_{2+\mathrm{x}} \mathrm{O}_{4}$ обладают близкими параметрами решётки. Однако, стехиометрия является важной характеристикой, определяющей свойства синтезируемых образцов феррита меди. Использование метода ДР позволило установить, содержание и стехиометрию феррита меди, а также состав примесных фаз, состоящих из оксидов меди, оксидов железа. Активность синтезируемых образцов ферритов меди была изучена в реакции каталитического гидролиза, а также гидротермолиза амминборана [2], который является перспективным способом получения водорода при температуре окружающей среды.

\section{Сиисок литературы}

1. Симагина В.И., Комова О.В., Одегова Г.В., Нецкина $\quad$ О.В., Булавченко О.А., Почтарь А.А., Кайль Н.Л.Исследование медь-железо смешанного оксида со структурой кубической шпинели, синтезированного методом горения //Журнал прикладной химии. 2019. Т.92. №1 С.24-34.

2. Komova O.V., Odegova G.V., Gorlova A.M., Bulavchenko O.A., Pochtar A.A., Netskina O.V., Simagina V.ICopperIron Mixed Oxide Catalyst Precursors Prepared by Glycine-Nitrate Combustion Method for Ammonia Borane Dehydrogenation Processes //International Journal of Hydrogen Energy. 2019. V.44. N44. P.24277-24291.

Работа выполнена при финансовой поддержке Министерства науки и высшего образования РФ в рамках государственного задания Института катализа СО РАН (проект № АAАA-A21-121011390006-0). 